\title{
System of quality labels in the European Union
}

\section{Tomáš Sadílek}

\section{University of Economics, Prague, Czech Republic}

\begin{tabular}{l} 
Keywords: \\
Label \\
Quality \\
DOOR database \\
EU \\
Food \\
\\
\hline
\end{tabular}

\section{Article history:}

Received 03.05.2016

Received in revised form 26.08.2016

Accepted 01.09.2016

\section{Corresponding \\ author:}

Tomáš Sadílek

E-mail:

tomas.sadilek@vse.cz

\section{Abstract}

Introduction. The paper deals with European Union schemes of Protected Designation of Origin, Protected Geographical Indication and Traditional Speciality Guaranteed labels used in agricultural and food products sector.

Materials and methods. Secondary data from the Database of Origin and Registration are used. Sample consists of 1,356 labels registered in this database to the 18th July 2016. The frequency of labels utilization is analysed according to country, type of label, and product classes.

Results and discussion. The task of the research is to analyse the utilization of these labels in European Union market according to selected criteria including type of label registered in each country, and number of agricultural products and foodstuffs registered as quality labels in total. As results show, the highest number of product names is registered under PDO label followed with slight difference by PGI label. There are only minimum product names registered as TSG. Dominating country is Italy followed other Mediterranean countries like France, Spain, Portugal and Greece. Based on product class, the most common classes are Fruits, vegetables and cereals (for PGI, PDO), Cheeses (PDO) and Meat products (TSG, PGI). This is confirmed by Pearson's chi-square test of independence in order to determine if significant differences do exist between frequency of using the labels and mentioned criteria. It is confirmed weak dependence between number of product names registered as PDO, PGI and TSG and country of origin, middle strong dependence between type of label and product classes where the label is used, and strong dependence between country of origin and the most often registered product class.

Conclusion. The PDO, PGI and TSG schemes bring benefits to consumers as well as to producers. Consumers are buying a product with specific value-adding qualities. 


\section{Introduction}

The paper is focused on the specific problem area of so-called quality labels and presents results of marketing research focused on analysis of using selected quality labels in European Union (EU) agricultural and food products market. The production of food and agricultural products is an important part of the European Union economy. European food and beverages play a major role in the cultural identity of European citizens and regions. High quality of European food is a key advantage for European agriculture. [1] Many food and agricultural products exhibit special characteristics linked to their geographical area, traditional composition or traditional production method.

An integral part of EU agricultural policy is an effort to improve food quality and safety. Also consumers in EU countries show growing interest in the quality as well as traditional products. This generates a demand for food and agricultural products with identifiable specific characteristics, in particular those linked to their geographical origin. Producers offering products with the value-adding attributes should communicate them on the marketplace and highlight the characteristics of their products to consumers. Agricultural product quality policy therefore should provide producers with the right tools to better identify and promote such products and protect them against unfair practices. [2] Protection of original and traditional food from the EU is not only an important factor in preserving cultural and national traditions in the member states of the EU but also an important dimension of marketing for producers, taking into consideration the consumers' interest and confidence. [3]

In order to allow producers to use the added value of their products as effectively as possible and to facilitate consumers' choice of food products, since 1992, the EU has established quality labels system known as Protected Designation of Origin (PDO), Protected Geographical Indication (PGI) and Traditional Speciality Guaranteed (TSG) to protect the names of these products ([4]; [2]). These three schemes have built on a long history of regional and traditional specialities, especially in southern European countries. [5] The image of the region of origin and the specific product characteristics create a unique identity for food products bringing in this way added value. [6] The PDO, PGI and TSG labels aim to provide consumers with clear information on the product origin or speciality character, enabling them to make more informed purchases and the best possible choices. [7]

\section{Literature review}

In the context of the topic, the terms "food quality" and "quality labels" are explained, followed by the specification of surveyed labels PDO, PGI and TSG. Quality label is a term for a symbol that can be put on a product or its packaging indicating that the product or the process to make the product complies with given standards and that this compliance has been certified. [8], [9] Quality labels guarantee compliance not only with current standards, but also with additional quality criteria determined in a corresponding certification system. A quality labels give added value to the products and are usually used in communication with end consumers. [10] According to [1], quality labels are an ambiguous category that covers many different things. They can be divided into obligatory (determined by legal rules and compulsory for all products in a given product category) and voluntary labels (bring competitive advantage for a product), into general (address all product quality characteristics) and specific labels (focused only on particular quality characteristics), or 
into regional, national, international and global labels. They can cover quality, safety, organic origin and other characteristics of product. [1], [8], [11], [12] More about influence of quality labels on its regional distribution offers. [13], [14], [15] [16]

Food quality labels are determined to promote and protect food products and should be a guarantee of quality products, their geographical origin, specific characteristics and/or production methods. [8] They give a legal protection of a product against imitation throughout the market and eliminate the misleading of consumers by non-genuine products, which may be of inferior quality; they help producers obtain a premium price for their authentic products, and finally they should give clearer information to consumers about product characteristics and facilitate identification of food products with certified quality. [17]

Following text is focused on EU quality labels scheme that identifies agricultural products and foodstuffs farmed and produced to exacting specifications. It includes Protected Designation of Origin (PDO) and Protected Geographical Indication (PGI) for agricultural products and foodstuffs as well as for wine and spirits (there are different rules for wine and spirits and they are not included in our analysis), and Traditional Speciality Guaranteed (TSG) for agricultural farm products and foodstuffs. While a PDO covers agricultural products and foodstuffs which are produced, processed and prepared in a given geographical area using recognised know-how, a PGI indicates a link with the geographical area in at least one of the stages of production, processing or preparation. The link with the area is therefore stronger for PDO; PGI is a more flexible regulation. For PDO food products, management conditions are regulated by very strict rules with the aim of obtaining high quality process [18], the link with the area is stronger; PGI is a more flexible regulation. A TSG highlights a product's traditional character, either in the composition or means of production. According to new Regulation on EU quality schemes for agricultural products and foodstuffs entered into force in the beginning of 2013, in order to be "traditional" proven usage on the market during at least 30 years (instead of 25) is now required [2], [19], [20].

\section{Material and methods}

The main purpose of marketing research was to analyse the use of PDO, PGI and TSG label registered in DOOR database for agricultural products and foodstuffs in EU market. The DOOR database includes a list of product names (agricultural products and foodstuffs) registered as PDO, PGI or TSG as well as names for which registration has been applied. PDO and PGI cover also wine and spirits, however there are different rules for those products (in particular Regulation (EC) No 1234/2007 for wines, Regulation (EEC) No $1601 / 91$ for aromatized wine products, and Regulation (EC) No 110/2008 for spirits) and they are not included in DOOR database as well as other products out of Regulation 1151/2012. [20] Geographical indications protected in the European Community for wines originating in Member States and third countries are registered in E-BACCHUS database, geographical indications for spirits are listed in E-SPIRIT-DRINKS database.

The DOOR database user can scan a list of product names registered as PDO, PGI or TSG (generally or in selected country), product names can be also sorted according to product classes. However, the user can always see just a list of products. Database does not offer a summarized data and their comparison. Research studies dealing with the topic are focusing only on partial aspects of quality labels like analysis of food products registered as PDO, PGI and TSG in selected countries [3], [21], analysis of customer loyalty and buying 
intention for PDO label [22], consumer awareness and perception of labels [7], [23], consumer behaviour [14], customer satisfaction [24], or impact of labels on customer loyalty. [25] As criteria of analysis we set country of origin and type of label. Specific research purposes were as follows:

To identify the frequency of PDO, PGI and TSG labels utilization, to compare using of the labels according to EU countries and to compare using of the labels according to product classes.

The secondary data from the Database of Origin and Registration (DOOR) database were used. In July 2016, DOOR database includes total number of 1,514 items, but some of them are on waiting list and there is not sure if they would be accepted. [16], [26] therefore, in our analysis we have calculated with sample of registered items only, i.e. 1,356 items. We have to notice, in database are not only European countries, but also China represented with 10 own products certified with PDO and PGI labels, Thailand has three PGI labels, Vietnam, Colombia, and India have one registered product name. In the analysis, we proceeded descriptive statistics and contingency tables, where we tested relations with Chisquare test.

\section{Results and discussion}

Research outcomes correspond with the date of $18^{\text {th }}$ July 2016, when 1,356 product items certified with PGI, PDO or TSG label were registered in the DOOR database. Sample structure is presented in Table 1.

Sample Characteristics ( $n=1,356$, in per cent), first $90 \%$ of cases

Table 1

** eggs, honey, various milk products excluding butter etc.

\begin{tabular}{|c|c|c|c|c|c|}
\hline \multirow{3}{*}{$\begin{array}{l}\text { Type } \\
\text { of Label }\end{array}$} & PGI & 45.05 & \multirow[t]{12}{*}{ Country } & Italy & 20.90 \\
\hline & PDO & 50.88 & & France & 17.2 \\
\hline & TSG & 3.98 & & Spain & 14.2 \\
\hline \multirow[t]{9}{*}{$\begin{array}{l}\text { Product } \\
\text { Class }\end{array}$} & $\begin{array}{l}1.6 \text { Fruits, vegetables and } \\
\text { cereals }\end{array}$ & 27.3 & & Portugal & 10.0 \\
\hline & 1.3 Cheeses & 17.3 & & Greece & 7.6 \\
\hline & 1.2 Meat products & 13.2 & & Germany & 6.5 \\
\hline & 1.1 Fresh meat & 11.4 & & $\begin{array}{l}\text { United } \\
\text { Kingdom }\end{array}$ & 4.4 \\
\hline & 1.5 Oils and fats & 9.5 & & Poland & 2.7 \\
\hline & $\begin{array}{l}\text { 2.4 Bread, pastry, cakes, other } \\
\text { baker's wares }\end{array}$ & 5.5 & & $\begin{array}{l}\text { Czech } \\
\text { Republic }\end{array}$ & 2.1 \\
\hline & 1.8 Other products of Annex I* & 4.2 & & Slovenia & 1.6 \\
\hline & $\begin{array}{l}1.4 \text { Other products of animal } \\
\text { origin** }\end{array}$ & 3.3 & & Other & 12.8 \\
\hline & Other & 9.25 & & & \\
\hline
\end{tabular}

As we can see in Table 1, the highest share has PDO label followed by PGI label. Number of registered PGI (611, i.e. 45.05\%) and PDO labels (691, i.e. 50.88\%) is relatively 
balanced, with the slight predominance of PDO. There are only minimum product names registered as TSG (54, i.e. 3.98\%). Based on product class, the most of labels were awarded for fruits, vegetables and cereals. The most frequently certified products come from Italy (284 registered product names as PGI, PDO and TSG, i.e. 20.94\% from all registered product names).

Frequency of PGI, PDO and TSG labels according to country is based on the list of all countries and product names registered in the DOOR database. The ranking of all countries according to total number of registered product names as PGI, PDO and TSG was created, see Table 2. Fields with the largest number of registered product names under PGI, PDO and TSG are highlighted in grey colour.

Table 2

Numbers of product names registered as PGI, PDO and TSG according to countries $(n=1,356$, in per cent $)$

* The Czech Republic and Slovakia has registered four the same product names as TSG. Because of this duplicity, the sum of per cent for TSG is higher and also total sum of per cent is higher than $100 \%$.

\begin{tabular}{|c|c|c|c|c|}
\hline Country & PGI & PDO & TSG & Total \\
\hline 1. Italy & 8.63 & 12.17 & 0.15 & $\mathbf{2 0 . 9 4}$ \\
\hline 2. France & 9.88 & 7.23 & 0.07 & $\mathbf{1 7 . 1 8}$ \\
\hline 3. Spain & 6.49 & 7.45 & 0.29 & $\mathbf{1 4 . 2 3}$ \\
\hline 4. Portugal & 5.24 & 4.72 & 0.07 & $\mathbf{1 0 . 0 3}$ \\
\hline 5. Greece & 2.06 & 5.53 & 0.00 & $\mathbf{7 . 6 0}$ \\
\hline 6. Germany & 5.60 & 0.88 & 0.00 & $\mathbf{6 . 4 9}$ \\
\hline 7. United Kingdom & 2.43 & 1.77 & 0.22 & $\mathbf{4 . 4 2}$ \\
\hline 8. Poland & 1.47 & 0.59 & 0.66 & $\mathbf{2 . 7 3}$ \\
\hline 9. Czech Republic & 1.70 & 0.44 & 0.35 & $\mathbf{2 . 1 4}$ \\
\hline 10. Slovenia & 0.81 & 0.59 & 0.22 & $\mathbf{1 . 6 2}$ \\
\hline 11. Belgium & 0.74 & 0.22 & 0.37 & $\mathbf{1 . 3 3}$ \\
\hline 12. Austria & 0.44 & 0.66 & 0.07 & $\mathbf{1 . 1 8}$ \\
\hline 13. Hungary & 0.52 & 0.44 & 0.07 & $\mathbf{1 . 0 3}$ \\
\hline 14. Netherlands & 0.37 & 0.44 & 0.07 & $\mathbf{1 . 0 3}$ \\
\hline 15. Slovakia & 0.74 & 0.07 & 0.22 & $\mathbf{1 . 0 3}$ \\
\hline 16. Finland & 0.15 & 0.37 & 0.22 & $\mathbf{0 . 7 4}$ \\
\hline 17. Lithuania & 0.29 & 0.07 & 0.15 & $\mathbf{0 . 5 2}$ \\
\hline 18. Sweden & 0.22 & 0.15 & 0.15 & $\mathbf{0 . 5 2}$ \\
\hline 19. Bulgaria & 0.15 & 0.00 & 0.29 & $\mathbf{0 . 4 4}$ \\
\hline 18. Denmark & 0.44 & 0.00 & 0.00 & $\mathbf{0 . 4 4}$ \\
\hline 19. Ireland & 0.29 & 0.07 & 0.00 & $\mathbf{0 . 3 7}$ \\
\hline 20. Latvia & 0.07 & 0.07 & 0.22 & $\mathbf{0 . 3 7}$ \\
\hline 21. Cyprus & 0.29 & 0.00 & 0.00 & $\mathbf{0 . 2 9}$ \\
\hline 22. Luxembourg & 0.15 & 0.15 & 0.00 & $\mathbf{0 . 3 0}$ \\
\hline 24. Romania & 0.15 & 0.07 & 0.00 & $\mathbf{0 . 2 2}$ \\
\hline Total & $\mathbf{5 0 . 9 6}$ & $\mathbf{4 5 . 0 6}$ & $\mathbf{3 . 6 9} *$ & $\mathbf{1 0 0 . 3 5}$ \\
\hline & & & & \\
\hline
\end{tabular}


As it is evident from Table 2, 24 from 27 EU member countries have registered their product names as PGI, PDO or TSG in DOOR database. Malta and Estonia have not yet used this type of protection. The first six countries of ranking in Table 2 (i.e. $22 \%$ of all EU countries) have obtained PDO, PGI and TSG labels for $80 \%$ product names registered in DOOR database (interestingly, the Pareto rule is shown here). The first three countries in the ranking, Italy, France and Spain, then have more than $50 \%$ of all registered product names. Italy has registered the highest number of product names as PDO; France is the first in number of PGI labels. It is interesting, that most of TSG labels belong to countries in weaker positions in the overall ranking, i.e. to Poland, Slovakia, Belgium and the Czech Republic.

In order to discover reciprocal dependences of tracked characters, we proceeded Chisquare test at significance level $\alpha=0.05$, when $\operatorname{sig} F=0$, and we can confirm variables depend reciprocally. Thereby, we accept stated hypothesis about highest distribution of labels in three Mediterranean countries, Italy, France and Spain. Reasons for this could be well-known gastronomic specialities as well as national cuisine of these countries, which have built on a long history and are popular around the world. Overall, these countries have higher impact on global food marketplace, comparing with countries such Luxembourg, Ireland and Lithuania, whose food products are not so popular in customers' minds. Relations in the sample are described by Pearson contingency coefficient $(0.520)$ and Cramer's contingency coefficient $(0.430)$, thus there is weak dependence between number of product names registered in the database and country of origin. These two contingency coefficients are the most basic measure of association between two nominal-level variables. [27]

Comparison of selected EU countries according to numbers of product names registered in the individual product classes.

In the last step of analysis, we compare EU countries by numbers of product names registered in the individual product classes. We wanted to know which product class is the most typical in each country. Because of too high number of items in the DOOR database, we have decided to focus only on countries which have registered more than 15 product names. This is ten first countries mentioned in Table 2 which have registered $87 \%$ (1180) items as PGI, PDO and TSG (in July 2016).

The most common product class is 1.6 (Fruits, vegetables and cereals) which is dominant in Italy, Spain, Greece and Poland. Portugal and Slovenia have the highest number of registered products in class 1.2 (Meat products), France in class 1.1 (Fresh meat), UK in class 1.3 (Cheeses). As we expected, the Czech Republic excels in class 2.1 (Beers). Germany is the only country represented in the class 2.2 (Mineral and spring waters) and at the same time this product class is dominant for Germany.

In order to discover dependency between country of origin and the most often registered product class, we proceeded Chi-square test at significance level $\alpha=0.05$, sig $\mathrm{F}$ $=0$ and we can confirm, there are dependencies between these variables. In the next step, we measured tightness size between same variables with using of Pearson contingency coefficient. Its value is 0.707 , which means strong positive dependence between country and the most often registered product class, i.e. each country has one important product class in which the most of domestic products is registered. Similar to the analysis of labels utilization by country of origin, we prove the most product types are registered in Italy, France and Spain. The most likely explanation is importance of these national food products at the global marketplace, where products like olive oils, cheeses, vegetable a fruit products play important role. 
In the literature, PDOs, PGIs and TSGs are usually modelled as a signal of high quality in a vertical differentiation context. In some countries, importance of PDOs, PGIs and TSGs is very high. For instance, in leading countries such France, Italy and Spain a high share of wine is sold under PGIs and important factors for this are soil, climate and traditional know-how, then there is a high importance of geographical location. There also exists real impact on national economies because smaller producers of agricultural and food products can benefit from well-established reputation of EU-wide known quality labels and can manufacture products with added value and differ from their competitors. Furthermore, it can affect positive impact on regional development in particular region in form of new jobs.

Success of utilization of European Union quality schemes is influenced by perception of quality in certain European countries. In southern Europe, customers willing to pay more for acquiring a good from a particular origin [28], but in northern Europe quality is associated more with a set of rules on safety, integrity, or conformity to industrial processes and there is not needed to support traditional know-how of certain geographical origin. Another case are French wines, which names are so well-known, that further geographical protection is not needed, because there are well-promoted brands (for instance Chateau Margaux, Georges Duboeuf, Mouton-Cadet).

The reason why countries such France, Italy and Spain dominate, is also long tradition of protection their food products prior nowadays European Union Quality Schemes. For instance, Roquefort, famous French cheese is protected since 15th century, when King Charles VI granted a monopoly for producers in Roquefort-sur-Soulzon only. Perhaps France has the biggest experiences with protection of certain food brands by organization called Appellation d'origine controlee.

\section{Conclusion}

Presented paper deals with analysis of European Union quality labels scheme known as PDO, PGI and TSG used in agricultural and food products sector. Data comes from the DOOR database and for obtaining outcomes, statistical methods have been used. The main contribution of the paper is a comprehensive view on the topic, the comparison of summarized data according to selected criteria including country of origin, type of label and product class, and statistical testing the relations between using of the labels and mentioned criteria. As results show, the highest number of product names is registered under PDO label followed with slight difference by PGI label. There is only minimum product names registered as TSG. Dominating country is Italy followed other Mediterranean countries like France, Spain, Portugal and Greece. The reason for this could be a long history of regional and traditional specialities in these countries and a higher importance of these products (such olive oil, cheeses, vegetable products and other) on the global marketplace. Based on product class, the most common classes are Fruits, vegetables and cereals (for PGI, PDO), Cheeses (PDO) and Meat products (TSG, PGI). In various countries dominate different product classes, but most frequent are, in consistency with previous results, classes Fruits, vegetables and cereals (Italy, Spain, Greece and Poland) and Meat products (Portugal and Slovenia). Beer is the most typical product class in the Czech Republic. Statistic testing has confirmed weak dependence between number of product names registered as PDO, PGI and TSG and country of origin, middle strong dependence between type of label and product classes where the label is used, and strong dependence between country of origin and the most often registered product class. 


\section{- Economics and Management -}

Original and traditional agricultural and food products can be perceived as an important part of tradition and image of the region. The PDO, PGI and TSG schemes bring benefits to consumers as well as to producers. Consumers are assured they are buying a genuine product with specific value-adding qualities. Producers benefits lies in fair competition, protection, and promotion of their products. To take full advantage of these benefits, producers should communicate their products with the value-adding attributes and highlight the specific character of their products to consumers, enabling them to make more informed purchases and the best possible choices. The aim of the communication campaign should be to build awareness, credibility and favourable perceptions about quality and distinctiveness of PDO, PGI and TSG products, and to stimulate consumers' interest in such products.

Acknowledgments. The research was supported by grant F2/94/2015 "Analysis of quality labels utilization in the Czech food market and efficiency of campaigns supporting them" at Faculty of International Relations, University of Economics, Prague.

\section{References}

1. Grunert K. G. (2005), Food quality and safety: consumer perception and demand, European Review of Agricultural Economics, 32, (3), pp. 369-391.

2. European Commission (2012a), Agricultural and rural development: Geographical indications and traditional specialities, European Union, available at: http://ec.europa.eu/agriculture/quality/schemes/index_en.htm

3. Nagyová L., Horská E., Kádeková, Z. (2011), Food quality policy and labelling, Delhi Business Review, 12, (1), pp. 85-100.

4. EUFIC (2013), Quality logos in the European Union, EUFIC, available at: http://www.eufic.org/article/en/artid/Quality-logos-in-the-European-Union/

5. Teuber R. (2010), Geographical indications of origin as a tool of product differentiation: The case of coffee, Journal of International Food and Agribusiness Marketing, 22, pp. 277-298.

6. van Ittersum K., Candel M. J. J. M. and Meulenberg M. T. G. (2003), The influence of the image of a product's region of origin on the product evaluation, Journal of Business Research, 56, pp. 215-226.

7. Verbeke W. et al. (2012), Consumers' awareness and attitudinal determinants of European Union quality label use on traditional foods, Bio-based and Applied Economics, 1, (2), pp. 213-229.

8. Velčovská Š., Marhounová M. (2005), Marketingové pojetí značky, VŠB-TUO, Ostrava.

9. United Nations (2007), Safety and quality of fresh fruit and vegetables. A training manual for trainers, United Nations, New York and Geneva, available at: http://www.unctad.org/en/docs/ditccom200616_en.pdf

10. The European Committee for the Valve Industry (2012), Standardisation guide for sanitary tapware, CEIR, 2007, available at: http://www.ceironline.org/data/File/Standardisation\%20guide\% 20for\%20sanitary\%20tapware.pdf

11. Velčovská Š. (2012), Food quality labels and their perception by consumers in the Czech Republic, World Academy of Science, Engineering and Technology, 66, pp. 154-160.

12. Petrova M., Kostova I., Vasileva N., Damyanova S., Ivanova I., Nakov G. (2015), Main tendencies in the town and rural consumers' interest forward the information 


\section{- Economics and Management -}

from the food labels, Proceedings University of Ruse „Angel Kanchev”, 54(10.2), pp. 188-194.

13. Dumitru Mnerie, Liviu Gaceu, Oleksii Gubenia, Mark Shamtsyan, Adriana Birca, Gabriela Victoria Mnerie (2016), Comparative study on the evolution of the food labeling quality in some countries from the Black Sea region, Journal of Hygienic Engineering and Design, 14, pp. 60-65.

14. Stefanov S. (2013), Information on labels for consumers, Upakovka, 5, pp. 20-22.

15. Petrova M., Ivanova N., Damyanova S., Kostova I., Ivanova I., Nakov Gj. (2015), Students' habits for informed choice of food and drinks Introduction, Journal of Food and Packaging Science, Technique and Technologies, 7, pp. 23-29.

16. Parrot, N., Wilson, N., Murdoch, J. (2002), Spatializing quality: regional protection and alternative geography of food, European Regional Studies. 9, (3), Pp. 241-261.

17. O'Connor and Company (2005), Geographical indications and the challenges for ACP countries, Agritrade, CTA, available at: http://agritrade.cta.int/en/ content/view/full/1794

18. Espejal J., Fandos C., Flavián C. (2008), Consumer satisfaction: A key factor of consumer loyalty and buying intention of a PDO food products, British Food Journal, 110, (9), pp. 865-881.

19. European Commission (2012b), Agricultural and rural development: PDO, PGI, TSG logos, European Union, available at:

http://ec.europa.eu/agriculture/quality/schemes/logos/index_en.htm

20. European Commission (2013c), Agricultural and rural development: EU agricultural product quality policy, European Union, available at:

http://ec.europa.eu/agriculture/quality/

21. Becker T., Staus A. (2008), European food quality policy: the importance of geographical indications, organic certification and food quality insurance schemes in European countries, European Association of Agricultural Economists 2008 International Congress 'People, Food and Environments: Global Trends and European Strategies', EAAE, Ghent, pp. 1-15.

22. Fandos C., Flavián C. (2006), Intrinsic and extrinsic quality attributes, loyalty and buying intention: an analysis for a PDO product, British Food Journal, 108, (8), pp. 646-662.

23. Velčovská Š., Janáčková H., Larsen F. (2012), Food quality labels; Insights from customers in two selected European countries, International Journal of Trade, Economics and Finance, 3, (1), pp. 52-58.

24. Espejal J., Fandos C., Flavián C. (2007), The role of intrinsic and extrinsic quality attributes on consumer behaviour for traditional food products, British Food Journal, 17, (6), pp. 681-701.

25. Chrysochou P., Krystallis P., Giraud G. (2012), Quality assurance labels as drivers of customer loyalty in the case of traditional food prducts, Food Quality and Preference, 25, (2), pp. 56-162.

26. European Commission (2013d), DOOR. [online], European Union, available at: $\mathrm{http}: / /$ ec.europa.eu/agriculture/quality/door/list.html

27. Blaikie N. W. (2003), Analyzing quantitative data: from description to explanation, SAGE Publications, London.

28. Lucatelli, S. (1999), Appelations of Origin and Geographical Indications in OECD Member Countries: Economic and Legal Implicaitions, OECD, Paris. 